\title{
Influence of Foetal Macrosomia on the Neonatal and Maternal Birth Outcome
}

\section{Einfluss einer fetalen Makrosomie auf den neonatalen und maternalen Geburtsausgang}

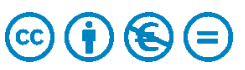

\author{
Authors \\ Tamara Margit Jutta Pahlitzsch, Laura Hanne, Wolfgang Henrich, Alexander Weichert
}

Affiliation

Klinik für Geburtsmedizin, Charité Universitätsmedizin Berlin, Berlin, Germany

Key words

foetal macrosomia, shoulder dystocia, gestational diabetes

Schlüsselwörter

fetale Makrosomie, Schulterdystokie, Gestationsdiabetes

$\begin{array}{ll}\text { received } & 29.11 .2018 \\ \text { revised } & 18.2 .2019 \\ \text { accepted } & 20.3 .2019\end{array}$

Bibliography

DOI https://doi.org/10.1055/a-0880-6182

Geburtsh Frauenheilk 2019; 79: 1191-1198 @ Georg Thieme

Verlag KG Stuttgart · New York | ISSN 0016-5751

Correspondence

Dr. Tamara Margit Jutta Pahlitzsch, MD

Klinik für Geburtsmedizin, Charité-Universitätsmedizin

Berlin

Augustenburger Platz 1, 13353 Berlin, Germany

tamara.pahlitzsch@charite.de

Deutsche Version unter:

https://doi.org/10.1055/a-0880-6182

\section{ABSTRACT}

Introduction Foetal macrosomia is associated with various obstetrical complications and is a common reason for inductions and primary or secondary Caesarean sections. The objective of this study is the generation of descriptive data on the mode of delivery and on maternal and foetal complications in the case of foetal macrosomia. The causes and consequences of foetal macrosomia as well as the rate of shoulder dystocia are examined in relation to the severity of the macrosomia.
Patients The study investigated all singleton births $\geq 37+0$ weeks of pregnancy with a birth weight $\geq 4000 \mathrm{~g}$ at the Charité University Medicine Berlin (Campus Mitte 2001-2017, Campus Virchow Klinikum 2014-2017).

Results 2277 consecutive newborns (birth weight 4000$4499 \mathrm{~g}$ [88\%], 4500-4999g [11\%], $\geq 5000 \mathrm{~g}$ [1\%]) were included. Maternal obesity and gestational diabetes were more common in the case of newborns weighing $\geq 4500 \mathrm{~g}$ than newborns weighing 4000-4499g $(\mathrm{p}=0.001$ and $\mathrm{p}<0.001)$. Women with newborns $\geq 5000 \mathrm{~g}$ were more often $\geq 40$ years of age $(p=0.020)$ and multipara $(p=0.025)$. The mode of delivery was spontaneous in $60 \%$ of cases, vaginal-surgical in $9 \%$, per primary section in $14 \%$ and per secondary section in $17 \%$. With a birth weight $\geq 4500 \mathrm{~g}$, a vaginal delivery was more rare $(p<0.001)$ and the rate of secondary sections was increased $(p=0.011)$. Women with newborns $\geq 4500 \mathrm{~g}$ suffered increased blood loss more frequently $(p=0.029)$. There was no significant difference with regard to the rate of episiotomies or serious birth injuries. Shoulder dystocia occurred more frequently at a birth weight of $\geq 4500 \mathrm{~g}$ ( 5 vs. $0.9 \%, p=0.000$ ). Perinatal acidosis occurred in $2 \%$ of newborns without significant differences between the groups. Newborns $\geq 4500 \mathrm{~g}$ were transferred to neonatology more frequently $(p<0.001)$. Conclusion An increased birth weight is associated with an increased maternal risk and an increased rate of primary and secondary sections as well as shoulder dystocia; no differences in the perinatal outcome between newborns with a birth weight of $4000-4499 \mathrm{~g}$ and $\geq 4500 \mathrm{~g}$ were seen. In our collective, a comparably low incidence of shoulder dystocia was seen. In the literature, the frequency is indicated with a large range $(1.9-10 \%$ at $4000-4499 \mathrm{~g}, 2.5-20 \%$ at $4500-$ $5000 \mathrm{~g}$ and $10-20 \%$ at $\geq 5000 \mathrm{~g}$ ). One possible cause for the low rate could be the equally low prevalence of gestational diabetes in our collective. A risk stratification of the pregnant women (e.g. avoidance of vacuum extraction, taking gestational diabetes into account during delivery planning) is crucial. If macrosomia is presumed, it is recommended that delivery take place at a perinatal centre in the presence of a specialist physician, due to the increased incidence of foetal and maternal complications. 


\section{ZUSAMMENFASSUNG}

Einleitung Eine fetale Makrosomie ist mit einer Vielzahl geburtshilflicher Komplikationen assoziiert und ein häufiger Grund für Einleitungen und primäre oder sekundäre Sectiones. Ziel dieser Studie ist die Generierung deskriptiver Daten zum Geburtsmodus und zu maternalen und fetalen Komplikationen bei fetaler Makrosomie. Ursachen und Folgen einer fetalen Makrosomie sowie die Rate an Schulterdystokien werden in Abhängigkeit von der Ausprägung der Makrosomie untersucht.

Patientinnen Ausgewertet wurden alle Einlingsgeburten $\geq 37+0$ Schwangerschaftswochen mit einem Geburtsgewicht $\geq 4000 \mathrm{~g}$ in der Charité Universitätsmedizin Berlin (Campus Mitte 2001-2017, Campus Virchow Klinikum 2014-2017).

Ergebnisse Eingeschlossen wurden 2277 konsekutive Neugeborene (Geburtsgewicht 4000-4499g [88\%], 4500$4999 \mathrm{~g}[11 \%], \geq 5000 \mathrm{~g}$ [1\%]). Maternale Adipositas und ein Gestationsdiabetes waren bei Neugeborenen $\geq 4500 \mathrm{~g}$ häufiger als bei $4000-4499 \mathrm{~g}(\mathrm{p}=0,001$ bzw. $\mathrm{p}<0,001)$. Frauen mit Neugeborenen $\geq 5000 \mathrm{~g}$ waren häufiger $\geq 40$ Jahre $(p=0,020)$ und Multipara $(p=0,025)$. Der Geburtsmodus war in $60 \%$ der Fälle spontan, in $9 \%$ vaginal-operativ, in $14 \%$ per primärer und in $17 \%$ per sekundärer Sectio. Bei einem Geburtsgewicht $\geq 4500 \mathrm{~g}$ war eine vaginale Geburt seltener $(p<0,001)$ und die Rate sekundärer Sectiones erhöht $(p=0,011)$. Frauen mit Neugeborenen $\geq 4500 \mathrm{~g}$ erlitten häufiger einen erhöhten Blutverlust $(p=0,029)$. Es bestand kein signifikanter Unterschied hinsichtlich der Rate an Episiotomien oder höhergradigen Geburtsverletzungen. Schulterdystokien traten vermehrt bei einem Geburtsgewicht $\geq 4500 \mathrm{~g}$ auf ( 5 vs. $0,9 \%, p=0,000$ ). Bei $2 \%$ der Neugeborenen trat eine perinatale Azidose auf ohne signifikante Unterschiede zwischen den Gruppen. Neugeborene $\geq 4500 \mathrm{~g}$ wurden häufiger in die Neonatologie verlegt $(p<0,001)$.

Schlussfolgerung Ein zunehmendes Geburtsgewicht ist mit einem erhöhten maternalen Risiko und einer erhöhten Rate an primären und sekundären Sectiones sowie Schulterdystokien verbunden, ohne dass sich Unterschiede im perinatalen Ausgang zwischen Neugeborenen mit einem Geburtsgewicht von $4000-4499 \mathrm{~g}$ und $\geq 4500 \mathrm{~g}$ zeigen. In unserem Kollektiv zeigte sich eine vergleichsweise niedrige Inzidenz an Schulterdystokien. In der Literatur ist die Häufigkeit mit einer großen Spannbreite angegeben $(1,9-10 \%$ bei $4000-4499 \mathrm{~g}$, $2,5-20 \%$ bei $4500-5000 \mathrm{~g}$ und $10-20 \%$ bei $\geq 5000 \mathrm{~g}$ ). Eine mögliche Ursache für die niedrige Rate könnte die ebenfalls geringe Prävalenz von Gestationsdiabetes in unserem Kollektiv sein. Eine Risikostratifizierung der Schwangeren (z. B. Vermeidung einer Vakuumextraktion, Berücksichtigung eines Gestationsdiabetes bei der Geburtsplanung) ist entscheidend. Bei vermuteter Makrosomie resultiert aus der erhöhten Inzidenz von fetalen und maternalen Komplikationen die Empfehlung zur Geburt in einem Perinatalzentrum unter Anwesenheit eines Facharztes.

\section{Introduction}

The term "foetal macrosomia" describes excessive intrauterine growth which leads to an increased birth weight. The exact definition is inconsistent. In most investigations, the limit is set at a birth weight of $\geq 4000 \mathrm{~g}$, but in some cases also at a weight of $\geq 4500 \mathrm{~g}$ [1-5]. Alternatively, excessive intrauterine growth can also be defined by growth above the 90th percentile (large for gestational age) [1].

According to the IQTIG - Institute for Quality Assurance and Transparency in Health, $8.9 \%$ of all newborns weighed $4000-$ $4499 \mathrm{~g}$ and $1.2 \% \geq 4500 \mathrm{~g}$ [6] in 2016 in Germany. In the analysis of the German perinatal survey data 2007-2011, no increase in birth weight was seen in Germany in comparison to the years 1995-1997 [7].

Relevant risk factors of macrosomia are the previous birth of a macrosomal child, gestational diabetes, particularly in the case of inadequately controlled blood glucose values, maternal obesity, significant weight gain during pregnancy, male sex of the foetus, exceeding $\geq 41+0$ weeks of pregnancy, as well as multiparity [ 3 , $4,8,9]$.

An increase in obstetrical complications as well as in maternal and foetal morbidity and mortality in cases of foetal macrosomia have been described in the literature. A major complication which increases with increasing birth weight is shoulder dystocia. In addition to foetal asphyxia, paralysis of the brachial plexus and a humeral fracture can occur as a result [10].
The other possible complications include increased postpartum bleeding and more severe birth injuries $[8,11]$. Foetal macrosomia also appears to increase the rate of stillbirths and Caesarean sections [2]. In addition, there is presumed to be an association between foetal macrosomia and a lower 5-minute Apgar score, postnatal hypoglycaemia, and foetal asphyxia [2, 3, 8, 12].

The suspected diagnosis of macrosomia frequently leads to uncertainty on the part of the parents as well as the attending obstetricians regarding possible complications and the suitable mode of delivery. The high degree of inaccuracy of the sonographic weight estimation at term should be taken into consideration, particularly in the case of macrosomal foetuses [5]. Chauhan et al. demonstrated in a review that the likelihood of diagnosing macrosomia was between 15 and 79\%. The sonographic weight estimation of a birth weight $\geq 4500 \mathrm{~g}$ was particularly unreliable [13]. Medical interventions such as inductions or preventive Caesarean sections to decrease the risks are the subject of controversial debate.

The risk of complications increases with an increasing degree of macrosomia. A U.S. cohort study by Boulet et al. showed that starting at a weight of $\geq 4000 \mathrm{~g}$, delivery complications occur more frequently, however neonatal morbidity increases significantly only starting at a weight of $\geq 4500 \mathrm{~g}$. Neonatal mortality increased at a weight of $\geq 5000 \mathrm{~g}$ [3]. Zhang et al. also observed an increase in neonatal morbidity starting at a weight of $\geq 4500 \mathrm{~g}$ [2].

These results illustrate the challenge of counselling expectant parents depending on the sonographic estimated weight in order 
to avoid unnecessary interventions and uncertainty. It should additionally be clarified which other factors should be taken into account during delivery planning and the extent to which the sonographic estimated weight can be relied on.

The objective of this study is the generation of descriptive data on the mode of delivery as well as on maternal and foetal complications in the case of foetal macrosomia. These data can be used to provide pregnant patients with evidence-based information and for joint decision-making regarding the mode of delivery if foetal macrosomia is suspected. The causes and consequences of foetal macrosomia should be investigated secondarily as a function of their degree of severity for an adverse maternal or child outcome as well as the investigation of the rate of shoulder dystocia in the various weight groups.

\section{Methodology}

\section{Patients}

All singleton live births $\geq 37+0$ weeks of pregnancy with a birth weight $\geq 4000 \mathrm{~g}$ at Charité University Medicine Berlin were evaluated. Data were extracted from the ViewPoint database (GE Healthcare, Solingen, Germany) and were available for the Campus Charité Mitte for the period 2001-2017 and for the Campus Virchow Klinikum for the period 2014-2017. Variables which were described in the literature as being influencing factors for macrosomia as well as the starting variables which can be potentially influenced by macrosomia were discussed. Perinatal acidosis was defined as an umbilical artery $\mathrm{pH}(\mathrm{UApH})$ of $<7.10$. An adverse perinatal outcome was defined based on the criteria for postnatal cooling as a $\mathrm{UApH}<7.0$, an umbilical artery base excess $(\mathrm{UA}-\mathrm{BE})<-16 \mathrm{mmol} / \mathrm{l}$ or a 10-minute Apgar value < 5 [14]. An adverse maternal outcome was defined as a severe birth injury (grade III or IV perineal laceration), need for an episiotomy or postpartum bleeding $\geq 500 \mathrm{ml}[15]$.

\section{Statistics}

All data were tested for a normal distribution $(-1<$ skew $>1)$. For variables with a normal distribution, mean values \pm standard deviations were determined, for variables with non-normal distributions, medians \pm interquartile ranges were determined, and for categorical variables, frequencies were determined. Newborns were divided for the subgroup analyses according to their birth weight into three $(4000-4499 \mathrm{~g}$ vs. $4500-4999 \mathrm{~g}$ vs. $\geq 5000 \mathrm{~g})$ and two (<4500 g vs. $\geq 4500 \mathrm{~g} ;<5000 \mathrm{~g}$ vs. $\geq 5000 \mathrm{~g})$ subgroups. Differences in risk factors for foetal macrosomia and mode of delivery and in the maternal and foetal outcome between the subgroups were examined for significance in descriptive analyses using Student's t test for continuous variables and $x^{2}$ test or Fisher's exact test for categorical variables. $P$ values for all variables were tested bilaterally and statistical significance was defined as $p \leq 0.05$. Cases with missing data were excluded for the analysis of the affected variables.

All analyses were performed using IBM SPSS Statistics 25.0 (IBM, Armonk, New York, USA).

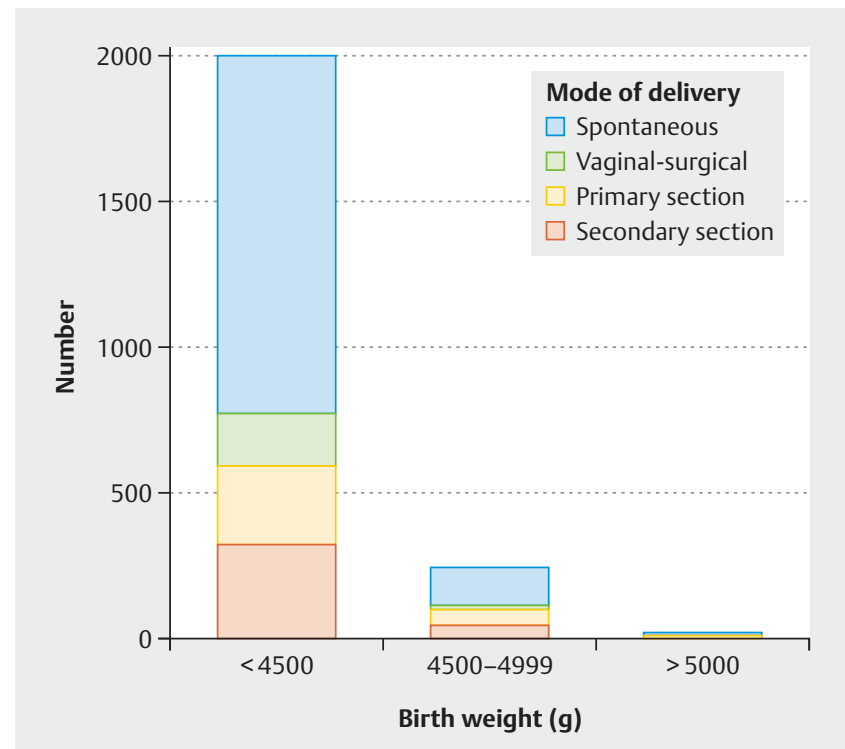

- Fig. 1 Representation of the mode of delivery in the weight classes $4000-4499 \mathrm{~g}, 4500-4999 \mathrm{~g}$ and $\geq 5000 \mathrm{~g}$. Primary and secondary sections were performed more frequently with an increasing birth weight.

\section{Results}

Of 2277 women included with macrosomal children, the children of 2005 (88\%) women had a birth weight between $4000-4499 \mathrm{~g}$, 249 (11\%) between 4500-4999 g and 23 (1\%) weighed $\geq 5000 \mathrm{~g}$ ( $\triangleright$ Table 1). Women with macrosomal children weighing $4500 \mathrm{~g}$ or more significantly differed from women with children between $4000-4499 \mathrm{~g}$ due to an increased incidence of obesity (26 vs. $17 \%, p=0.001$ ) and diabetes in pregnancy ( 9 vs. $4 \%, p<0.001$ ). Women with macrosomal children $\geq 5000 \mathrm{~g}$ were more frequently $\geq 40$ years ( 22 vs. $7 \%, p=0.020$ ) and more frequently multiparous (17 vs. $5 \%, p=0.025)(\triangleright$ Table 1$)$.

\section{Mode of delivery}

The mode of delivery was spontaneous in 1371 (60\%) of all patients, vaginal-surgical in 194 (9\%) per primary section in 326 (14\%) and per secondary section in 385 (17\%) (> Table 2 [15]). Children with a birth weight of $4000-4500 \mathrm{~g}$ were significantly more frequently delivered vaginally (spontaneous or vaginal-surgical) and the rate of vaginal-surgical deliveries in the case of children $\geq 4500 \mathrm{~g}$ was not significantly elevated. The rate of inductions and the method of induction did not significantly differ between the children with a birth weight above or below $4500 \mathrm{~g}$. Excluding primary sections, the rate of secondary sections in children at a weight of $\geq 4500 \mathrm{~g}$ was significantly increased as compared to those between $4000-4500 \mathrm{~g}(\triangleright$ Fig. 1). The rate of emergency sections was not significantly increased ( $\vee$ Table 2 ). Half $(n=11)$ of newborns with a birth weight of $\geq 5000 \mathrm{~g}$ were born spontaneously. 
- Table 1 Demographic characteristics of the study cohorts, divided according to birth weight.

\begin{tabular}{|c|c|c|c|c|c|}
\hline \multirow[t]{2}{*}{ Variable } & $4000-4499 \mathrm{~g}$ & $4500-4999 \mathrm{~g}$ & $\geq 5000 \mathrm{~g}$ & all & $\mathbf{p}$ \\
\hline & $2005(88 \%)$ & $249(11 \%)$ & $23(1 \%)$ & 2277 & \\
\hline \multirow[t]{2}{*}{ Age $\geq 40$ years } & $138(7 \%)$ & $18(7 \%)$ & $5(22 \%)$ & \multirow[t]{2}{*}{$161(7 \%)$} & \\
\hline & \multicolumn{2}{|l|}{$156(7 \%)$} & $5(22 \%)$ & & $0.020^{* *}$ \\
\hline Week of pregnancy & $40.2( \pm 1.0)$ & \multicolumn{2}{|l|}{$40.1( \pm 1.1)$} & $40.2( \pm 1.0)$ & 0.307 \\
\hline \multirow[t]{2}{*}{ Diabetes } & \multirow[t]{2}{*}{$74(4 \%)$} & $19(8 \%)$ & $6(26 \%)$ & \multirow[t]{2}{*}{$99(4 \%)$} & 0.000 \\
\hline & & $25(9 \%)$ & & & 0.000 \\
\hline - dGDM & $42(2 \%)$ & $6(2 \%)$ & $4(17 \%)$ & $52(2 \%)$ & \multirow[t]{4}{*}{0.000} \\
\hline - iGDM & $24(1 \%)$ & $10(4 \%)$ & $1(4 \%)$ & $35(2 \%)$ & \\
\hline - DMT1 & $5(0.2 \%)$ & $1(0.4 \%)$ & 0 & $6(0.3 \%)$ & \\
\hline - DMT2 & $3(0.1 \%)$ & $2(0.8 \%)$ & $1(4 \%)$ & $6(0.3 \%)$ & \\
\hline \multirow[t]{2}{*}{ Weight prior to pregnancy $\leq 80 \mathrm{~kg}$} & \multirow[t]{2}{*}{$476(24 \%)$} & $77(32 \%)$ & $9(39 \%)$ & \multirow[t]{2}{*}{$562(25 \%)$} & 0.013 \\
\hline & & $86(32 \%)$ & & & 0.005 \\
\hline \multirow[t]{2}{*}{ Obesity (BMI $\geq 30$ prior to pregnancy) $\left({ }^{* 116}\right)$} & \multirow[t]{2}{*}{$331(17 \%)$} & $59(25 \%)$ & $8(35 \%)$ & \multirow[t]{2}{*}{$398(18 \%)$} & \\
\hline & & $67(26 \%)$ & & & 0.001 \\
\hline Weight gain during pregnancy $(\mathrm{kg})\left({ }^{* 253}\right)$ & 16 (IQR 12-20) & 17 (IQR 13-21) & 16 (IQR 12-21) & 16 (IQR 12-20) & $0.103^{* * *}$ \\
\hline \multirow[t]{2}{*}{ Sex, male $\left({ }^{* 1}\right)$} & \multirow[t]{2}{*}{$1282(64 \%)$} & $168(68 \%)$ & $15(65 \%)$ & \multirow[t]{2}{*}{$1465(64 \%)$} & 0.552 \\
\hline & & $183(67 \%)$ & & & 0.285 \\
\hline \multirow[t]{2}{*}{ Multipara $\left({ }^{* 4}\right)$} & $98(5 \%)$ & $16(6 \%)$ & & $114(5 \%)$ & 0.475 \\
\hline & \multicolumn{2}{|l|}{$110(5 \%)$} & $4(17 \%)$ & & $0.025^{* *}$ \\
\hline Unipara $\left({ }^{* 4}\right)$ & $798(40 \%)$ & $86(35 \%)$ & $8(35 \%)$ & $888(39 \%)$ & 0.289 \\
\hline \multicolumn{5}{|l|}{ Post-term } & \\
\hline " $\leq 40+0$ & $781(39 \%)$ & $101(41 \%)$ & $13(57 \%)$ & $895(39 \%)$ & \\
\hline - $40+1-41+6$ & $1196(60 \%)$ & $145(58 \%)$ & $10(44 \%)$ & $1351(59 \%)$ & \\
\hline . $\geq 42+0$ & $28(1 \%)$ & $3(1 \%)$ & 0 & $31(1 \%)$ & \\
\hline $\begin{array}{l}\text { Only spontaneous, vaginal-surgical } \\
\text { or sec. section mode of delivery }\end{array}$ & $1737(89 \%)$ & $197(10 \%)$ & $16(1 \%)$ & 1950 & \\
\hline \multirow[t]{2}{*}{ Induction $\left({ }^{* 15}\right)$} & \multirow[t]{2}{*}{$658(38 \%)$} & $84(44 \%)$ & $5(31 \%)$ & \multirow[t]{2}{*}{$747(39 \%)$} & \\
\hline & & $89(43 \%)$ & & & 0.170 \\
\hline \multicolumn{5}{|l|}{ Induction method $\left({ }^{* 3}\right)$} & \\
\hline - Minprostin vaginal gel & $198(30 \%)$ & $28(32 \%)$ & & $226(30 \%)$ & \\
\hline - Misoprostol oral & $321(49 \%)$ & $45(51 \%)$ & & $366(49 \%)$ & \\
\hline - Long-term oxytocin infusion & $126(19 \%)$ & $13(15 \%)$ & & $139(19 \%)$ & \\
\hline - Amniotomy & $5(1 \%)$ & $3(3 \%)$ & & $8(1 \%)$ & \\
\hline - Other & $5(1 \%)$ & 0 & & $5(1 \%)$ & \\
\hline \multicolumn{6}{|c|}{$\left({ }^{* n}\right)$ : Number of missing data for the variable } \\
\hline \multicolumn{6}{|c|}{ ** Fisher's exact test (instead of $x^{2}$ test, if expected $\mathrm{n}$ of a group $<5$ ) } \\
\hline \multicolumn{6}{|c|}{ *** p value based on the Mann-Whitney U test $<4500 \mathrm{~g}$ vs. $\geq 4500 \mathrm{~g}$. } \\
\hline
\end{tabular}

\section{Neonatal outcome}

Of the macrosomal children, 57 (2\%) had perinatal acidosis; there was no significant difference between children $<4500 \mathrm{~g}$ and $\geq 4500 \mathrm{~g}$ ( $\triangleright$ Fig. 2). Seven children had a 10-minute Apgar < 5; all children from the group with a weight of 4000-4500 g. Children with a birth weight of $\geq 4500 \mathrm{~g}$ were transferred postnatally to a neonatology ward far more frequently ( $\bullet$ Table 3 [14]). Overall, shoulder dystocia occurred rarely in the case of vaginal delivery (1\%) and was noted to occur more frequently at a birth weight $\geq 4500 \mathrm{~g}$. The rate of shoulder dystocia did not significantly differ between women who underwent induction or who had no induction ( $n=6[1.1 \%]$ vs. $n=14$ [1.4\%], $p=0.599$ ). Shoulder dystocia occurred in 2 out of 11 vaginal deliveries $>5000 \mathrm{~g}$ ( $>$ Table 3). There were three cases of brachial plexus paresis and one humeral fracture in a total of 20 cases of shoulder dystocia. 
- Table 2 Maternal outcome classified according to birth weight.

\begin{tabular}{|c|c|c|c|c|c|}
\hline Variable & $4000-4499 \mathrm{~g}$ & $4500-4999 \mathrm{~g}$ & $\geq 5000 \mathrm{~g}$ & all & $\mathbf{p}$ \\
\hline All modes of delivery & $2005(88 \%)$ & $249(11 \%)$ & $23(1 \%)$ & 2277 & \\
\hline \multicolumn{5}{|l|}{ Mode of delivery $\left({ }^{* 1}\right)$} & \multirow[t]{5}{*}{$0.000^{* * * *}$} \\
\hline - Spontaneous & $1229(61 \%)$ & $131(53 \%)$ & $11(50 \%)$ & $1371(60 \%)$ & \\
\hline - Vaginal-surgical & $179(9 \%)$ & $15(6 \%)$ & $0(0 \%)$ & $194(9 \%)$ & \\
\hline - Prim. section & $268(13 \%)$ & $52(21 \%)$ & $6(27 \%)$ & $326(14 \%)$ & \\
\hline - Sec. section & $329(16 \%)$ & $51(20 \%)$ & $5(23 \%)$ & $385(17 \%)$ & \\
\hline Mode of delivery, vaginal $\left({ }^{* 1}\right)$ & $1408(70 \%)$ & $146(59 \%)$ & $11(50 \%)$ & $1565(69 \%)$ & 0.000 \\
\hline \multicolumn{5}{|l|}{ Bleeding $\left({ }^{* 95}\right)$} & \multirow[t]{4}{*}{0.001} \\
\hline . $<500 \mathrm{ml}$ & $1157(60 \%)$ & \multicolumn{2}{|l|}{$118(48 \%)$} & $1275(58 \%)$ & \\
\hline - 500-999 ml & $666(34 \%)$ & \multicolumn{2}{|l|}{$108(44 \%)$} & $774(35 \%)$ & \\
\hline . $\geq 1000 \mathrm{ml}$ & $112(6 \%)$ & \multicolumn{2}{|l|}{$21(9 \%)$} & $133(6 \%)$ & \\
\hline Adverse maternal outcome ${ }^{* * *}\left({ }^{* 166}\right)$ & $799(42 \%)$ & $81(44 \%)$ & $15(71 \%)$ & $895(42 \%)$ & 0.023 \\
\hline $\begin{array}{l}\text { Only spontaneous or vaginal-surgical } \\
\text { mode of delivery }\end{array}$ & $1408(90 \%)$ & $146(9 \%)$ & $11(1 \%)$ & 1565 & \\
\hline \multicolumn{5}{|l|}{ Birth injury $\left({ }^{* 12}\right)$} & \\
\hline - None & $685(49 \%)$ & $71(50 \%)$ & $5(46 \%)$ & $761(49 \%)$ & \\
\hline - Grade I/II perineal laceration & $450(32 \%)$ & $45(32 \%)$ & $5(46 \%)$ & $500(32 \%)$ & \\
\hline - Grade III/IV perineal laceration & $31(2 \%)$ & $2(1 \%)$ & 0 & $33(2 \%)$ & \\
\hline - Cervical laceration & $9(1 \%)$ & $2(1 \%)$ & 0 & $11(1 \%)$ & \\
\hline - Other & $226(16 \%)$ & $21(15 \%)$ & $1(9 \%)$ & $248(16 \%)$ & \\
\hline Birth injury, severe $\left({ }^{* 12}\right)$ & $40(3 \%)$ & \multicolumn{2}{|l|}{$4(3 \%)$} & $44(3 \%)$ & $1.000^{* *}$ \\
\hline Episiotomy $\left({ }^{* 9}\right)$ & $326(23 \%)$ & \multicolumn{2}{|l|}{$38(25 \%)$} & $364(23 \%)$ & 0.692 \\
\hline \multirow[t]{2}{*}{ Blood loss $\geq 500 \mathrm{ml}\left({ }^{* 58}\right)$} & \multirow[t]{2}{*}{$190(14 \%)$} & $26(19 \%)$ & $4(36 \%)$ & \multirow[t]{2}{*}{$220(15 \%)$} & \\
\hline & & $30(21 \%)$ & & & 0.029 \\
\hline \multirow[t]{2}{*}{ Adverse maternal outcome ${ }^{* * *}\left({ }^{* 58}\right)[15]$} & $256(19 \%)$ & \multirow[t]{2}{*}{$35(24 \%)$} & & \multirow[t]{2}{*}{$291(19 \%)$} & 0.121 \\
\hline & $286(19 \%)$ & & $5(46 \%)$ & & 0.043 \\
\hline Vaginal-surgical delivery & $178(13 \%)$ & \multicolumn{2}{|l|}{$15(10 \%)$} & $193(12 \%)$ & 0.264 \\
\hline $\begin{array}{l}\text { Only spontaneous, vaginal-surgical } \\
\text { or sec. section mode of delivery }\end{array}$ & $1737(89 \%)$ & $197(10 \%)$ & $16(1 \%)$ & 1950 & \\
\hline \multirow[t]{2}{*}{ Sec. section } & \multirow[t]{2}{*}{$329(19 \%)$} & $51(26 \%)$ & $5(31 \%)$ & \multirow[t]{2}{*}{$385(20 \%)$} & \\
\hline & & \multicolumn{2}{|l|}{$56(26 \%)$} & & 0.011 \\
\hline Emergency section & $22(1 \%)$ & $3(2 \%)$ & 0 & $25(1 \%)$ & $0.749^{* * * *}$ \\
\hline Drug-based induction $\left({ }^{* 15}\right)$ & $657(38 \%)$ & $89(43 \%)$ & & $746(39 \%)$ & 0.165 \\
\hline \multicolumn{6}{|c|}{$\left({ }^{* n}\right)$ : Number of missing data for the variable } \\
\hline \multicolumn{6}{|c|}{ ** Fisher's exact test (instead of $x^{2}$ test, if expected $n$ of a group $<5$ ) } \\
\hline \multicolumn{6}{|c|}{ *** Grade III/IV perineal laceration, bleeding $>500 \mathrm{ml}$, hysterectomy [15] } \\
\hline \multicolumn{6}{|c|}{${ }^{* * * *}$ p value based on the $\chi^{2}$ test $<4500 \mathrm{~g} \mathrm{vs.} \geq 4500 \mathrm{~g}$} \\
\hline
\end{tabular}

\section{Maternal outcome}

133 women (6\%) suffered blood loss of $\geq 1000 \mathrm{ml}$, whereby women with children $\geq 4500 \mathrm{~g}$ did not demonstrate increased blood loss significantly more frequently. However, following vaginal delivery, women with children $\geq 4500 \mathrm{~g}$ suffered a blood loss of $\geq 500 \mathrm{ml}$ far more frequently.

In the case of a vaginal delivery, 44 women experienced a serious birth injury (grade III/IV perineal laceration: 33 [2\%], cervical laceration 11 [1\%]) and 364 (23\%) underwent episiotomy, where- by there was no significant difference in each case between a birth weight of $<4500 \mathrm{~g}$ and of $\geq 4500 \mathrm{~g}$ ( $>$ Table 2 ).

\section{Discussion}

Foetal macrosomia is one of the most common complications in pregnancy.

Our results show that an increasing birth weight is associated with an increase in obstetrical complications, whereby the risk of 


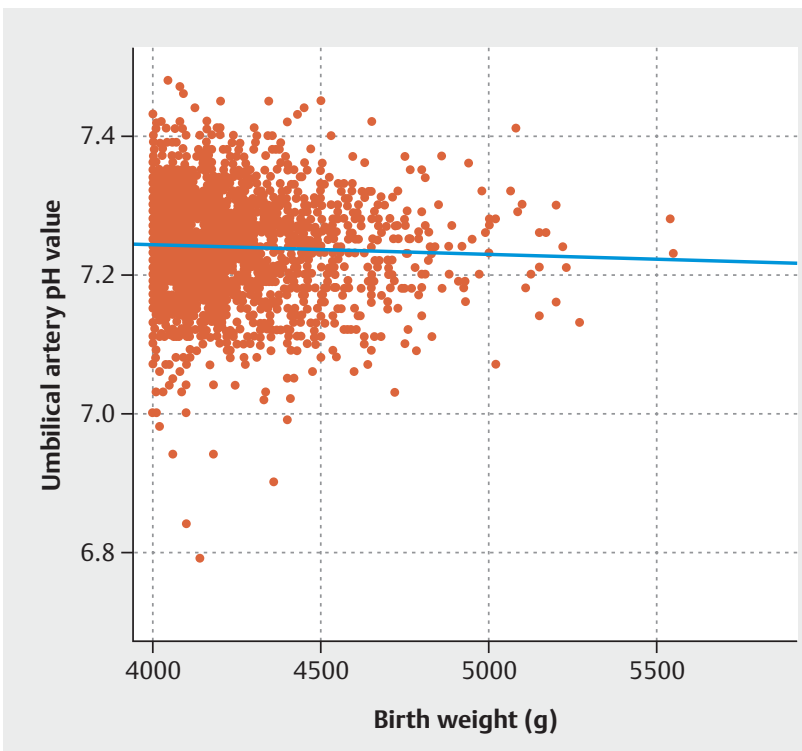

- Fig. 2 UA-pH depending on birth weight. No difference in the various weight groups was observed.

severe complications, such as shoulder dystocia with potentially long-term damage, is significantly increased at a weight $\geq 4500 \mathrm{~g}$. Nevertheless, even at a birth weight $\geq 4500 \mathrm{~g}$, vaginal delivery was the most common mode of delivery and was possible without complications in the majority of cases.

In accordance with already published data, maternal obesity, diabetes in pregnancy, multiparity and maternal age correlate with an increasing birth weight $[3,8]$. In our collective, there was no difference between the various groups with regard to maternal weight gain during pregnancy. However, a meta-analysis from 2016 showed that excess weight gain can lead to an increased risk of foetal macrosomia [4]. Since this is a risk factor which can be influenced, providing information to the pregnant patients as well as regular weight checks in accordance with the maternity guidelines are relevant.

Our study demonstrates a significantly increased risk of shoulder dystocia at a birth weight of $\geq 4500 \mathrm{~g}(5 \%)$ versus a weight of 4000-4499 g (0.9\%). In 20 newborns, brachial plexus paresis occurred in three cases and a humeral fracture occurred in one case.

In two of the newborns with brachial plexus paresis, the shoulder dystocia was able to be resolved using the McRoberts manoeuvre and suprasymphyseal pressure. In the third case, the newborn was able to be delivered only after the additional use of the Rubin manoeuvre.

With regard to data already published, the occurrence of shoulder dystocia in our collective is comparatively low. However, the frequency is indicated with a large range $(1.9-10 \%$ in the case of $4000-4499 \mathrm{~g}, 2.5-20 \%$ in the case of $4500-5000 \mathrm{~g}$ and $10-$ $20 \%$ in the case of $\geq 5000 \mathrm{~g}$ ), which can possibly be attributed to the inconsistent definition and individual estimation [16-20]. Shoulder dystocia is diagnosed in our clinic if, after the birth of the child's head, the head retracts back into the vulva-perineal region in a "turtle" phenomenon and, despite traction in a dorsal and caudal direction, the anterior shoulder can only be delivered through further manoeuvres [21].

If gestational diabetes is present, the risk is additionally significantly increased [22]. A possible cause for our low rate could be the similarly low prevalence of gestational diabetes in our collec-

- Table 3 Foetal outcome divided according to birth weight.

\begin{tabular}{|c|c|c|c|c|c|}
\hline Variable & $4000-4499 \mathrm{~g}$ & $4500-4999 \mathrm{~g}$ & $\geq 5000 \mathrm{~g}$ & all & $\mathbf{p}$ \\
\hline All modes of delivery & $2005(88 \%)$ & $249(11 \%)$ & $23(1 \%)$ & 2277 & \\
\hline 10-Minute Apgar < $5\left({ }^{* 23}\right)$ & $7(0.4 \%)$ & 0 & & $7(0.3 \%)$ & $1.000^{* *}$ \\
\hline \multicolumn{5}{|l|}{$\mathrm{UApH}\left({ }^{* 36}\right)$} & \\
\hline - $\geq 7.1$ & $1930(98 \%)$ & $233(97 \%)$ & $21(96 \%)$ & $2184(98 \%)$ & \\
\hline . 7-7.09 & $41(2 \%)$ & $8(3 \%)$ & $1(5 \%)$ & $50(2 \%)$ & \\
\hline.$<7$ & $7(0.4 \%)$ & 0 & 0 & $7(0.3 \%)$ & \\
\hline $\mathrm{UApH}<7.1\left({ }^{* 36}\right)$ & $48(2 \%)$ & \multicolumn{2}{|l|}{$6(2 \%)$} & & 0.885 \\
\hline $\mathrm{BE}<-16 \mathrm{mmol} / \mathrm{I}\left({ }^{* 154}\right)$ & $7(0.4 \%)$ & \multicolumn{2}{|l|}{$1(0.4 \%)$} & $8(0.4 \%)$ & $1.000^{* *}$ \\
\hline \multirow[t]{2}{*}{ Transfer to neonatology $\left({ }^{* 22}\right)$} & \multirow[t]{2}{*}{$194(10 \%)$} & $39(16 \%)$ & $7(33 \%)$ & \multirow[t]{2}{*}{$240(11 \%)$} & \\
\hline & & \multicolumn{2}{|l|}{$46(18 \%)$} & & 0.000 \\
\hline Adverse perinatal outcome ${ }^{* * *}\left({ }^{* 24}\right)$ & $14(1 \%)$ & \multicolumn{2}{|l|}{$1(0.4 \%)$} & $15(1 \%)$ & $1.000^{* *}$ \\
\hline $\begin{array}{l}\text { Only spontaneous or vaginal-surgical } \\
\text { mode of delivery }\end{array}$ & $1408(90 \%)$ & $146(9 \%)$ & $11(1 \%)$ & 1565 & \\
\hline \multirow[t]{2}{*}{ Shoulder dystocia } & \multirow[t]{2}{*}{$12(0.9 \%)$} & $6(4 \%)$ & $2(18 \%)$ & \multirow[t]{2}{*}{$20(1 \%)^{*}$} & \\
\hline & & $8(5 \%)$ & & & $0.000^{* *}$ \\
\hline \multicolumn{6}{|c|}{$\left({ }^{* n}\right)$ : Number of missing data for the variable } \\
\hline \multicolumn{6}{|c|}{ ** Fisher's exact test (instead of $x^{2}$ test, if expected $n$ of a group $<5$ ) } \\
\hline \multicolumn{6}{|c|}{ *** Apgar $10 \mathrm{~min}<5, \mathrm{pH}<7, \mathrm{BE}<-16 \mathrm{mmol} / \mathrm{l}$ (corresponding to the cooling criteria: [14]) } \\
\hline
\end{tabular}


tive (4\% in the case of a foetal weight of $4000-4499 \mathrm{~g}, 9 \%$ in the case of a weight of $\geq 4500 \mathrm{~g}$ ).

The significant increase in the risk of shoulder dystocia in the case of maternal gestational diabetes, induction of delivery, and a vaginal-surgical delivery should be taken into account [16].

A risk stratification of the pregnant women (e.g. avoidance of vacuum extraction, taking gestational diabetes into account during delivery planning) is crucial in order to avoid this complication.

In this investigation, the occurrence of perinatal acidosis in the case of a higher birth weight was not significantly increased. However, newborns $\geq 4500 \mathrm{~g}$ were more frequently transferred to the neonatology intensive care unit. Other studies saw a significant increase in neonatal morbidity at a weight of $\geq 4500 \mathrm{~g}$. At a weight of $4000-4500 \mathrm{~g}$, no [2] or only a minor increase [3] in neonatal morbidity versus normosomal newborns was observed.

Maternal complications occurred more frequently than foetal complications.

In vaginal deliveries, women with newborns $\geq 4500 \mathrm{~g}$ more frequently experienced increased blood loss than women with newborns between $4000-4499 \mathrm{~g}$. Therefore, following the birth of a macrosomal child, bleeding prophylaxis using misoprostol or a long-term oxytocin infusion should be considered, along with the active management of the postpartum period by means of oxytocin, as recommended by the WHO [23].

A vaginal delivery was the most common mode of delivery in all groups. However, the proportion of vaginal deliveries decreased in the case of a birth weight $\geq 4500 \mathrm{~g}$ and the proportion of secondary sections increased.

If macrosomia is suspected in a foetus, the question of the optimal mode of delivery arises in clinical practice. There is currently no general recommendation regarding the sonographic estimated weight at or above which an induction or primary section is advisable. During the consultation, the limited meaningfulness of the sonographic weight estimation, particularly in the case of macrosomal foetuses, should also be considered [13]. In a Cochrane analysis from 2016, an induction in the case of foetal macrosomia had no effect on the rate of sections. However, an induction reduced the birth weight as well as the occurrence of shoulder dystocia. No effect on the occurrence of plexus injuries could be demonstrated [24].

In the recently published ARRIVE study, pregnant women who underwent induction starting at $39+0$ weeks of pregnancy even underwent a section more rarely than in the control group with expectant management [25].

In the S3 guideline "Gestational diabetes mellitus", an individual approach with regard to an induction is recommended in the case of gestational diabetes. In principle, however, this should be considered starting at week $37+0$ of pregnancy, particularly in the case of insulin-dependent diabetes and a foetal weight $\geq 95$ th percentile. The authors additionally recommend a primary section in the case of an estimated weight of $\geq 4500 \mathrm{~g}$ [26 - 28]. If there is no gestational diabetes, the American College of Obstetricians and Gynecologists recommends a preventive section starting at $5000 \mathrm{~g}$. Induction is not recommended [1].

In summary, the pregnant patient must be informed in detail of the advantages and disadvantages of the respective mode of delivery. Possible consequences of a primary section with regard to a subsequent pregnancy and delivery should be discussed in particular, such as the increased risk of uterine rupture, placenta praevia, or an abnormally invasive placenta. The individual recommendation should also include aspects such as the course of previous deliveries, the presence of gestational diabetes, the physical constitution and the motivation of the pregnant woman. During the birth, it should be noted that a vaginal-surgical delivery increases the risk of shoulder dystocia [11]. The descriptive data collected in this study can be used in conjunction with other studies as a basis.

One limitation of this study are the low numbers of cases for the groups with a weight of $4500-4999$ and $\geq 5000 \mathrm{~g}$. For this reason, these were summarised for many subanalyses.

In addition, we did not evaluate any data on normosomal newborns. Therefore no statements on the possible causes of foetal macrosomia can be made.

Because of the retrospective nature of the investigation, the data sets are incomplete to some extent. Due to a change in process data acquisition, only data starting in 2014 at one site were able to be included in the study. Due to the nature of the facility as a level 1 perinatal centre, a selection bias also has to be assumed, such that the evaluation could not be used to determine prevalence.

\section{Conclusion}

An increasing birth weight is associated with an increased maternal risk and an increased rate of primary and secondary sections as well as shoulder dystocia, with no differences seen in the perinatal outcome between newborns with a birth weight of 4000-4499 g and $\geq 4500 \mathrm{~g}$. By contrast, maternal complications, particularly increased blood loss, were significantly increased in the case of a vaginal birth of a child $\geq 4500 \mathrm{~g}$. Overall, a vaginal delivery was possible without complications in the majority of cases, even in the case of macrosomia. From the data generated and the increased rate of transfers to the neonatology ward, it can be seen that, particularly if high-grade foetal macrosomia is suspected, the delivery should take place in a perinatal centre with the availability of experienced obstetricians, midwives and paediatricians and the pregnant patient must receive individual counselling beforehand.

\section{Conflict of Interest}

The authors declare that they have no conflict of interest.

\section{References}

[1] American College of Obstetricians and Gynecologists' Committee on Practice Bulletins-Obstetrics. Practice Bulletin No. 173: Fetal Macrosomia. Obstet Gynecol 2016; 128: e195-e209

[2] Zhang X, Decker A, Platt RW et al. How big is too big? The perinatal consequences of fetal macrosomia. Am J Obstet Gynecol 2008; 198: 517. e1-517.e6

[3] Boulet SL, Alexander GR, Salihu HM et al. Macrosomic births in the united states: determinants, outcomes, and proposed grades of risk. Am J Obstet Gynecol 2003; 188: 1372-1378 
[4] Tian C, Hu C, He X et al. Excessive weight gain during pregnancy and risk of macrosomia: a meta-analysis. Arch Gynecol Obstet 2016; 293: 29-35

[5] Lanowski JS, Lanowski G, Schippert C et al. Ultrasound versus Clinical Examination to Estimate Fetal Weight at Term. Geburtsh Frauenheilk 2017; 77: 276-283

[6] Institut für Qualitätssicherung und Transparenz im Gesundheitswesen. Bundesauswertung zum Erfassungsjahr 2016. 12.07.2017. Online: https://iqtig.org/downloads/auswertung/2016/16n1gebh/QSKH_16n1GEBH_2016_BUAW_V02_2017-07-12.pdf; last access: 18.01.2019

[7] Voigt M, Wittwer-Backofen U, Scholz R et al. Analysis of the German perinatal survey of the years 2007-2011 and comparison with data from 1995-1997: neonatal characteristics and duration of pregnancy. Z Geburtshilfe Neonatol 2013; 217: 211-214

[8] Stotland NE, Caughey AB, Breed EM et al. Risk factors and obstetric complications associated with macrosomia. Int J Gynaecol Obstet 2004; 87: 220-226

[9] Ehrenberg HM, Mercer BM, Catalano PM. The influence of obesity and diabetes on the prevalence of macrosomia. Am J Obstet Gynecol 2004; 191: 964-968

[10] Gross SJ, Shime J, Farine D. Shoulder dystocia: predictors and outcome. A five-year review. Am J Obstet Gynecol 1987; 156: 334-336

[11] Herzberg S, Kabiri D, Mordechai T et al. Fetal macrosomia as a risk factor for shoulder dystocia during vacuum extraction. J Matern Fetal Neonatal Med 2017; 30: 1870-1873

[12] Oral E, Cagdas A, Gezer A et al. Perinatal and maternal outcomes of fetal macrosomia. Eur J Obstet Gynecol Reprod Biol 2001; 99: 167-171

[13] Chauhan SP, Grobman WA, Gherman RA et al. Suspicion and treatment of the macrosomic fetus: a review. Am J Obstet Gynecol 2005; 193: 332346

[14] Peliowski-Davidovich A; Canadian Paediatric Society, Fetus and Newborn Committee. Hypothermia for newborns with hypoxic ischemic encephalopathy. Paediatr Child Health 2012; 17: 41-46

[15] Fuchs F, Bouyer ], Rozenberg P et al. Adverse maternal outcomes associated with fetal macrosomia: what are the risk factors beyond birthweight? BMC Pregnancy Childbirth 2013; 13: 90

[16] Nesbitt TS, Gilbert WM, Herrchen B. Shoulder dystocia and associated risk factors with macrosomic infants born in California. Am J Obstet Gynecol 1998; 179: 476-480

[17] Hill MG, Cohen WR. Shoulder dystocia: prediction and management. Womens Health (Lond) 2016; 12: 251-261
[18] Turkmen S, Johansson S, Dahmoun M. Foetal Macrosomia and FoetalMaternal Outcomes at Birth. J Pregnancy 2018; 2018: 4790136

[19] Alsunnari S, Berger $H$, Sermer $M$ et al. Obstetric outcome of extreme macrosomia. J Obstet Gynaecol Can 2005; 27: 323-328

[20] Kehila M, Derouich S, Touhami O et al. Macrosomia, shoulder dystocia and elongation of the brachial plexus: what is the role of caesarean section? Pan Afr Med J 2016; 25: 217

[21] Deutsche Gesellschaft für Gynäkologie und Geburtshilfe; Arbeitsgemeinschaft Medizinrecht. S1-Leitlinie: Empfehlungen zur Schulterdystokie. Erkennung, Prävention und Management. AWMF 015/024. 2010 (2013 abgelaufen). Online: https://www.dggg.de/fileadmin/documents/leitlinien/archiviert/federfuehrend/015024_Empfehlungen_zur_Schulterdystokie/015024_2010.pdf; last access: 17.02.2019

[22] Langer O, Rodriguez DA, Xenakis EM et al. Intensified versus conventional management of gestational diabetes. Am J Obstet Gynecol 1994; 170: 1036-1046; discussion 1046-1037

[23] World Health Organization. WHO recommendations for the prevention and treatment of postpartum haemorrhage. Geneva: WHO; 2012. Online: https://apps.who.int/iris/bitstream/handle/10665/75411/ 9789241548502_eng.pdf?sequence=1; last access: 12.05.2019

[24] Boulvain M, Irion O, Dowswell T et al. Induction of labour at or near term for suspected fetal macrosomia. Cochrane Database Syst Rev 2016; (5): CD000938. doi:10.1002/14651858.CD000938.pub2

[25] Grobman WA, Rice MM, Reddy UM et al. Labor Induction versus Expectant Management in Low-Risk Nulliparous Women. N Engl J Med 2018; 379: 513-523

[26] Deutsche Gesellschaft für Gynäkologie und Geburtshilfe; Deutsche Diabetes Gesellschaft. S3-Leitlinie Gestationsdiabetes mellitus (GDM), Diagnostik, Therapie und Nachsorge, 2. Auflage (2018). Online: https:// www.deutsche-diabetes-gesellschaft.de/fileadmin/Redakteur/Leitlinien /Evidenzbasierte_Leitlinien/2018/057-008I_S3_Gestationsdiabetesmellitus-GDM-Diagnostik-Therapie-Nachsorge_2018-03.pdf; last access: 18.02.2019

[27] Schafer-Graf UM. Gestational Diabetes - Major New Clinically Relevant Aspects. Geburtsh Frauenheilk 2018; 78: 977-983

[28] Schäfer-Graf UM, Gembruch U, Kainer F et al. Gestational Diabetes Mellitus (GDM) - Diagnosis, Treatment and Follow-Up. Guideline of the DDG and DGGG (S3 Level, AWMF Registry Number 057/008, February 2018). Geburtsh Frauenheilk 2018; 78: 1219-1231 